NOTES

\title{
THE ENTRUSTER'S RIGHT TO PROCEEDS OF SALE UNDER SECTION 10 OF THE UNIFORM TRUST RECEIPTS ACT
}

The Uniform Trust Receipts Act (UTRA) ${ }^{1}$ provides a chattel security device designed to facilitate credit transactions between financers, manufacturers, and dealers of consumer durables. ${ }^{2}$ In the typical transaction the bank or finance company (entruster) pays the manufacturer for goods sold and delivered to the dealer (trustee), ${ }^{3}$ receiving in return a security interest in the goods under a trust receipt executed by the dealer. ${ }^{4}$ The trust receipt ar-

1. Reprinted in 9A UNIFORA LAWs ANN. 284-317 (hereinafter cited as U.L.A.). The Uniform Trust Receipts Act (hereinafter cited as UTRA) was approved by the National Conference of Commissioners on Uniform State Laws in 1933, id. at 274, and has been adopted by thirty-two states and remains the law of thirty-one. Pennsylvania adopted the Uniform Commercial Code repealing the UTRA, PA. Stat. Ann. tit. 12A (Purdon 1954).

2. The trust receipt was originally devised by commercial banks for use in financing of import shipments and received common law recognition as early as 1843 . For the early history of trust receipts see Frederick, The Trust Receipt as Security, 22 Colum. L. REv. 395,546 (1922). When the UTRA was drafted in 1933 the common law trust receipt was being employed extensively to finance domestic shipments of automobiles and other consumer durables. At this same period of development, however, courts treated this device differently from state to state and the utility of the trust receipt was being curtailed by rather sterile legal technicalities. Some courts thought that in its "true nature" the trust receipt was just another form of pledge, chattel mortgage or conditional sale, and consequently that a trust receipt could create a valid security interest only by conforming to the legal requirements of the device with which it was identified. Other courts apparently recognized what they called "tripartite" arrangements in which the dealer acquired the goods or documents of title from the entruster, but invalidated "bipartite" arrangements permitting acquisition directly from the manufacturer. The UTRA was drafted to obviate this legal formalism, to promote uniformity, and to preserve the trust receipt for its growing commercial utilization. Commissioners' Prefatory Note, Why the Uniform Trust Receipts Act Was Drafted, 9A U.L.A. 274-77; Gilmore, Chattel Security: II, 57 YALE L.J. 761-65 (1948); notes 3, 4, 11. infra and accompanying text.

3. The manufacturer generally forwards bills of lading covering shipments directly to the entruster who gives copies to the dealer in exchange for trust receipts. But when bills of lading are forwarded first to the dealer, this departure from what was considered a "tripartite" arrangement does not invalidate the transaction. UTRA $\$ 2-1$ (b) ; Universal Credit Co. v. Citizens State Bank, 224 Ind. 1, 64 N.E.2d 28 (1945). For detailed discussion of the trust receipt transaction see Gilmore \& BLACK, AdMrralty \$\$ 3-21 (to be published, Foundation Press, 1957).

4. If a statement of trust receipt financing has been properly filed, the entruster's security interest in the goods is superior to that of all the dealer's purchasers, creditors and lienors, UTRA $\$ 7$, except buyers in the ordinary course of trade, id. $\$ 9-2(\mathrm{a})$; purchasers of negotiable instruments or documents and of "as if" negotiable instruments, $i d$. $\$$ 9-1 (a) ; and encumbrancers whose liens arise in connection with the processing, warehousing, shipping, etc., of the goods, $i d$. $\$ 11$.

A simple statement of trust receipt financing, filed with the Secretary of State by the 
rangement permits the dealer to sell the goods in the ordinary course of trade free of the entruster's security interest, ${ }^{5}$ but requires the dealer to repay his debt to the entruster immediately upon sale. ${ }^{6}$ As long as the dealer liquidates his trust receipt debts in this manner he is permitted to execute new trust receipts to finance replacement inventory, thus receiving a continuing line of credit. ${ }^{7}$ When the dealer defaults by retaining the proceeds of sale, the UTRA undertakes to protect the entruster; section 10 provides that his security interest shifts to these proceeds ${ }^{8}$ and survives for ten days. ${ }^{9}$ The UTRA thus seeks to give both dealer and financer the advantages of floating liens, but it avoids the two features which have traditionally led courts to hold floating liens illegal. ${ }^{10}$ In the first instance, the dealer's power of sale is distinguished from that associated with floating lien arrangements primarily by the requirement that his debt be immediately liquidated. ${ }^{11}$ Secondly, the UTRA gives

entruster, designating the dealer and containing a general description of the goods, fulfills all recordation requirements for one year. Id. $\$ 13$. Since this provision affords an inexpensive (usually one dollar) and convenient filing procedure, failure to file has not become a commercially significant problem in the field of dealer financing. Gilmore, The Commercial Doctrine of Goad Faith Purchase, 63 Y YLE L.J. 1057, 1103 (1954). But sce Note, 66 YALE L.J. 567 (1957) (discussing choice of proper place to file multistate transaction under UTRA).

5. UTRA § 9-2(a).

6. Section 10, which shifts the entruster's security interest to the proceeds, is operative only if the dealer has no liberty of sale, or having liberty of sale is to account for proceeds. The entruster derives no benefit from withholding liberty of sale since under $\$ 9-2$ (a) (ii) a buyer in the ordinary course of trade takes free of the entruster's interest despite such a limitation. In fact if the entruster does not give power of sale, and thus imposes no duty to account, the security arrangement is more likely to be invalidated under the doctrine of Benedict v. Ratner, 268 U.S. 353 (1925). It is probably for these reasons that the terms of the trust receipt agreement always impose on the dealer a duty to account to the entruster for proceeds immediately upon sale. See Heindl, Trust Receipt Financing Under the Uniform Trust Receipts Act, 26 CHI.-Kenr L. Rev. 197, 257 (1948).

7. In nearly all trust receipt arrangements the entruster sends a letter of credit in favor of the dealer to the manufacturer. This instrument generally states the volume of goods which the dealer may order during a specific period and contains the entruster's promise to pay the manufacturer for these goods by accepting all drafts which are accompanied by proper shipping documents. The entruster, however, retains the right to revoke the letter of credit, and presumably will revoke, if the dealer fails to maintain an expected rate of repayment. See Gilmore, Chattel Security: II, 57 YALE L.J. 761-62, 768 (1948); McGowan, Trust Receipts 14-15 (1947).

8. See pages $928-31$ infra.

9. See note 58 infra and accompanying text.

10. In most states liens are said to "float," and are held illegal as a fraud on creditors, when the borrower is given power to sell collateral with no correlative duty to account immediately to the lienor for the proceeds, and the security agreement provides that the lien shifts to after-acquired inventory. Cohen \& Gerber, Mortgages of Merchandise, 39 Corvar. L. Rev. 1338 (1939) (discussing different state definitions of floating liens and collecting cases) ; Cohen \& Gerber, The After-Acquired Property Clause, 87 U. PA. L. Rev. 635, 656-59 (1939) (same); Gilmore \& Axelrod, Chattel Security: I, 57 YALE L.J. 517, 534-35 (1948).

11. See note 6 supra, and authorities cited note 10 supra. 
the entruster the equivalent of a continuous security interest in a moving stock of goods, but in contrast to a floating lien, the entruster's ten day lien shifts not to after-acquired inventory, but to the proceeds of sale.

Despite these dissimilarities from the typical floating lien, the entruster's claim to a lien on proceeds under section 10 may encounter serious difficulty. The proceeds of dealer sales are usually conditional sales contracts. Since the dealer often discounts these contracts with the entruster, the former's loan is paid and no lien problems arise. ${ }^{12}$ In some instances, however, the dealer assigns the contracts for value to a second bank or finance company. In these cases, the entruster will seek to preserve his security interest by asserting a lien under section 10 either on the conditional sales contracts or on the proceeds received by the dealer from discounting the chattel paper. The second type of lien presents difficult bankruptcy problems. Since the proceeds retained by the dealer will generally be commingled with his other assets, they can seldom be traced and identified. Because of the unclear language of section 10 and the paucity of judicial interpretation, it is as yet uncertain whether this section authorizes a lien on unidentifiable proceeds and whether such a lien is enforceable in bankruptcy. ${ }^{13}$ The entruster would therefore prefer to establish a lien on the conditional sales contracts. In this context, he would not be involved in bankruptcy proceedings since he claims only against the assignee; outside of bankruptcy, a lien on such identifiable proceeds has always been held valid. ${ }^{14}$ Furthermore, sustaining his claim, the entruster would receive the interest payments on the conditional sales contracts. The claim would be challenged, however, by the assignee of the conditional sales contract, asserting his rights as a bona fide purchaser under section $9 .{ }^{15}$ In sum, the practical value of the entruster's security interest depends on two unsettled issues: whether the assignee can prevail over the entruster claiming under section 10 and thereby retain the conditional sales contracts; and, if so, whether the entruster can still retrieve this loss by claiming a section 10 lien on the unidentifiable proceeds of the sale.

To defeat the entruster's claim to the conditional sales contracts, the assignee argues that he fits within section 9-1(a), which provides that a good faith purchaser for value of instruments which "are by common practice purchased

12. The principal reason that banks and finance companies enter into trust receipt arrangements is to obtain conditional sales contracts from dealers. Trust receipt financing is carried out at comparatively low rates with little profit to the financer, while the financing of consumer sales under conditional sales contracts is a highly profitable enterprise. Thus, in most instances, dealer financing will be discontinued when a dealer fails to assign substantially all of this consumer paper to his entruster. Gilmore, The Commercial Doctrine of Good Faith Purchase, 63 YALE L.J. 1057, 1102 (1954).

13. In the only case in which this problem was presented, the court held that $\$ 10$ did establish a valid consensual lien on unidentifiable proceeds. In the Matter of Harpeth Motors, Inc., 135 F. Supp. 863 (M.D. Tenn. 1955).

14. Universal Credit Co. v. Citizens State Bank, 224 Ind. 1, 64 N.E.2d 28 (1945). See cases cited note 16 infra.

15. See notes 16 and 17 infra. 
and sold as if negotiable" holds such instruments free of the entruster's interest if he took them "by transfer in the customary manner." The few cases which have considered the assignee's section 9 argument have disagreed as to its merits. Some courts have upheld the entruster's claim, reasoning that section 9-1 (a) is not applicable to conditional sales contracts. ${ }^{10}$ But several cases have allowed the assignee of the chattel paper to avoid the entruster's claim. ${ }^{17}$ The section can easily be construed to compel the latter result. Since section 9-1 (a)'s phrase "purchased and sold as if negotiable" is not specifically defined by the statute, its meaning may be inferred from usage; section 9-1(a)'s insistance on a transfer "in the customary manner" may suggest that an instrument which is transferred in the manner in which negotiable instruments are transferred is one which is "purchased and sold as if negotiable." If, as seems likely, the "customary manner" of transfer is by indorsement and delivery, conditional sales contracts, which are customarily so transferred, are "purchased and sold as if negotiable." The good faith assignee for value then is entitled to retain these "as if negotiable" contracts if he took them by indorsement and delivery. 18

16. Canandaigua Nat'l Bank and Trust Co. v. Commercial Credit Corp., 285 App. Div. 7, 135 N.Y.S.2d 66 (4th Dep't 1954) ; General Motors Acceptance Corp. v. Associates Discount Corp., 38 N.Y.S.2d 972 (Mun. Ct. 1942), rev'd on other grounds, 267 App. Div. 1032, 48 N.Y.S.2d 242 (4th Dep't 1944) ; B.S.C. Corp. v. Colonial Discount Co., 169 Misc. 711, S N.Y.S.2d 65 (City Ct. 1938).

17. Citizens Nat'l Trust and Sav. Bank v. Beverly Finance Co., 127 Cal. App. 2d 835, 273 P.2d 714 (1954); Bank of America Nat'l Trust \& Sav. Ass'n v. National Funding Corp., 45 Cal. App. 2d 320, 114 P.2d 49 (1941) ; Farmers Nat'l Bank v. Universal Credit Co., 259 App. Div. 955, 20 N.Y.S.2d 1004 (3d Dep't 1940). See also North American Acceptance Corp. v. Northern Ill. Corp., 347 Ill. App. 89, 106 N.E.2d 197 (1952) (\$ 9-1(a) held applicable by implication but entruster prevailed since assignee was not good faith purchaser for value).

The assignee's alternative argument that he was a buyer in the ordinary course of trade under \$ 9-2(a) was indorsed in Bank of America Nat'l Trust \& Sav. Ass'n v. National Funding Corp., supra, but rejected in B.S.C. Corp. v. Colonial Discount Co., supra note 16.

18. Gilmore, The Commercial Doctrine of Good Faith Purchase, 63 YAle L.J. 1057, 1103-0t (1954).

Section 9-1(a) applies only to "instruments." Section 1 defines "instrument" as a "credit ... instrument of a sort marketed in the ordinary course of business or finance, of which the trustee, after the trust receipt transaction, appears by virtue of possession and the face of the instrument to be the owner." Arguably, conditional sales contracts are within this definition. Id. at 1104. Alternatively, it may be argued that $\$ 9-1$ (a) usage, "instruments ... sold as if negotiable" is not meant to be tested by the instrument definition of $\S 1$.

In either event the strong similarity between the basic characteristics of negotiable instruments and conditional sales contracts further suggests that the latter are in fact "purchased and sold as if negotiable." The presumptions of NegotIABLE INSTRUMents LAw $\$ \$ 24,16,14,59$, implementing a policy of free negotiability, encourage the transferee to accept an instrument "complete and regular on its face" as evidence of a valid debt substantially free from latent defects. The assignee of a conditional sales contract similarly relies on its regularity. Neither the transferee of a negotiable instrument nor the assignee of a conditional sales contract takes free from all defenses. The assignee may be subject to consumer's defenses such as breach of warranty; the transferee is 
Commercial policy favors a construction that would place conditional sales contracts within the "as if negotiable" category of section 9-1(a). A considerable body of statutory and case law denies full negotiability to conditional sales contracts. ${ }^{19}$ But the purpose of denying full negotiability is to enable the consumer to assert against the assignee-financer those defenses which would be good against the dealer. This purpose should not be persuasive in the totally different context of two institutional lenders asserting competing equities of ownership. ${ }^{20}$ In fact it would be more to the consumer's advantage for the assignee to take free of the entruster's lien. Allowing the entruster to maintain his security interest in this paper after assignment would tend to decrease competition among consumer credit financers, and consequently to exert an unfavorable influence on interest rates charged consumers. ${ }^{21}$ On the other hand, the interpretation of section 9-1(a) suggested above would enhance the mobility of chattel paper, thus serving the interest of the consumer credit industry which is substantially dependent on such ready assignability. ${ }^{22}$

Protecting the assignee's interest does introduce the possibility of abuse. Most cases litigated dealing with the relative rights of the entruster and assignee

subject to such real defenses as fraud on the drawer or maker. For so-called "real defenses" to negotiable instruments, see $i d$. $\S 55$. In each case the transferee or assignee relies on the regularity of his instrument; real defects are considered as risks of the enterprise rather than as risks of the particular transaction.

An additional argument may be premised on the fact that under the law of most states promissory notes do not lose their negotiable character when attached to conditional sales contracts. Gilmore, supra at 1097 \& n.119. Section 9-1(a) clearly applies to negotiable instruments. Consequently, even if it is held not to apply to conditional sales contracts, the assignee who loses his claim to the entruster could conceivably still retain the negotiable notes. Since the common law rule is that the security follows the note, id. at 1081-82 \& n.83, a construction of $\$ 9-1$ (a) which deemed it inapplicable to conditional sales contracts would be of little value to the entruster and would promote duplication of law suits.

19. Conditional sales contracts do not meet the requisites of negotiability as set out in Negotiable Instrunsents Law \$§ 1-10. See, e.g., Gale \& Co. v. Wallace, 210 Ark. 161, 163, 194 S.W.2d 881, 882 (1946); General Motors Acceptance Corp. v. Davis, 169 Kan. 220, 218 P.2d 181 (1950).

20. Gilmore, The Commercial Doctrine of Good Faith Purchase, 63 YALE L.J. 1057, 1101 (1954).

21. Prohibitive financing rates charged consumers on installment loans under conditional sales contracts have long been a serious problem. Note, 60 YALE L.J. 1218 (1951); Gilmore, The Commercial Doctrine of Good Faith Purchase, 63 YALE L.J. 1057 (1954). A partial solution has been effected in some states under statutes protecting the consumer's right to choose between financers and requiring dealers adequately to inform consumers as to all elements of the financing arrangement. See, e.g., N.Y. Pers. Prop. Law \$\$ 301-11. See Gilmore, The Secured Transactions Article of the Commercial Code, 16 Law \& Contearp. Prob. 27, 37 (1951); Donaldson, An Analysis of Retail Installment Sales Legislation, 19 Rocky MT. L. REv. 135 (1946). This desirable trend could be derogated, however, by allowing entrusters to monopolize dealer consumer paper. UNIFORM COMMreRctal CodE \$ 9-306, comment 2(c); id. \$ 9-308 (1956 Recommendations of the Editorial Board) ; Note, 61 Yale L.J. 718, 727 (1952).

22. Gilmore, The Commercial Doctrine of Good Faith Purchase, 63 YALE L.J. 1057, 1093-1102 (1954). 
of a conditional sales contract arise when the dealer corporation has purported to sell a trust receipted automobile on credit to its president, a relative or an employee. ${ }^{23}$ This enables the dealer who assigns the fictitious vendee's conditional sales contract to a second finance company to obtain two loans on the same security, which never leaves the premises. Under the UTRA the entruster must normally bear the risk of a dealer's dishonesty since he is deemed to be in the best position to scrutinize the dealer's activities. ${ }^{24}$ But even with frequent and careful investigation it is impossible for the entruster to prevent such fictitious sales. On the other hand, the assignee, whose normal inquiry about the automobile consumer will often disclose whether he has any connection with the dealer corporation, is in a relatively good position to prevent this type of double financing. ${ }^{25}$

The good faith proviso of section 9 is, however, a sufficient safeguard against abuse. Section 9 protects the second financer's claim to the conditional sales contract only when he can successfully meet the burden of persuasion as to his own good faith. ${ }^{26}$ Actual notice of the entruster's lien on the specific item sold prevents the assignee from proving good faith. ${ }^{27}$ However, the assignee seldom has such notice; in practice, he may only know that the dealer generally engages in trust receipt financing. In a bona fide sale, this kind of notice should be irrelevant and the assignee should be held in good faith. ${ }^{28}$ Since the chattel leaves the dealer's premises after a bona fide sale, the assignee may expect that the entruster in policing the dealer's inventory will learn that the chattel is missing, will demand an accounting and be paid from the amount given by the assignee to the dealer for the conditional sales contract. But if the assignee knows that the sale is fictitious and has notice that the dealer is usually financed through trust receipts, his participtation in the scheme demonstrates his own dishonesty. If he should have reason initially to suspect a close relationship

23. The seven cases reported in notes 16 and 17 supra are all cases of fictitious sales.

24. Commissioner's Prefatory Note, 9A U.L.A. 278.

25. See Seidman, Finance Companies and Factors 129 (1949).

26. See page 924 supra. North Am. Acceptance Corp., v. Northern Ill. Corp., 347 IIl. App. S9, 106 N.E.2d 197 (1952).

27. Gilmore, The Comnerical Doctrine of Good Faith Purchase, 63 YALE L.J. 1057, 1105 (1954) (reasoning from $\S 9-1$ (a) which provides that "filing under this act shall nat be deemed to constitute notice of the entruster's interest to purchasers in good faith ...," that a purchaser with actual notice of the entruster's security interest cannot retain the conditional sales contract); General Motors Acceptance Corp. v. Associates Discount Corp., 38 N.Y.S.2d 972, 978-79 (Mun. Ct. 1942) (dictum; same), rev'd, 267 App. Div. 1032, 48 N.Y.S.2d 242 (4th Dep't 1944). Cf. B.C.S. Corp. v. Colonial Discount Co., 169 Misc. 711, 713, 8 N.Y.S.2d 65, 67 (City Ct. 1938) (chattel mortgage).

28. All of the cases considering this notice problem in the context of a bona fide sale transaction have held that the assignee's knowledge of the dealer's general practice to engage in trust receipt financing does not constitute notice that the particular automobile under the conditional sales contract is subject to a trust receipt lien. Commercial Credit Co. v. Barney Motor Co., 10 Cal. 2d 718, 76 P.2d 1181 (1938); Tharp v. San Joaquin Valley Securities Co., 20 Cal. App. 2d 20, 66 P.2d 230 (1937). Cf. Peoples Finance and Thrift Co. v. Bowman, 58 Cal. App. 2d 729, 137 P.2d 729 (1943). 
between dealer and vendee and makes no further attempt to determine the nature of the sale and to discover whether the automobile is entrusted, his participation at least evidences a lack of good faith. When the claim arises out of a sale which was in fact fictitious, there should be a presumption of bad faith, rebuttable by a showing either that the assignee had no reason to suspect a close relationship between dealer and vendee, or that after exercising reasonable care the assignee could not discover both that the automobile was entrusted property and that the vendee was fictitious. This presumption is consistent with the policy of the UTRA, since it is premised not on the assignee's assumption of the risk of dealer dishonesty, but on the assignee's own bad faith in participating in the scheme when a reasonable financer would have made further inquiries.

If the entruster loses his claim to the conditional sales contract the extent of his recovery from a defaulting dealer may often depend on how his interest in unidentifiable proceeds is classified in federal bankruptcy proceedings. Proceeds which remain subject to the entruster's claim under section 10 of the UTRA are those realized by the dealer from the sale of entrusted goods or the assignment of consumer paper. When the dealer is in default it is likely that bankruptcy is imminent and that these cash proceeds are commingled with his other assets and are unidentifiable. Under $10(\mathrm{~b})$ :

“. . . the entruster [is] entitled, to the extent to which and as against all classes of persons as to whom his security interest was valid at the time of disposition by the trustee, ... to any proceeds or the value of any proceeds (whether such proceeds are identifiable or not) of the goods, ... if said proceeds were received by the trustee within ten days prior to either ... the filing of a petition in bankruptcy ... by or against the trustee, or demand made by the entruster for prompt accounting; and to a priority to the anount of such proceeds or value..." [Emphasis added.]

If this section is interpreted to establish for the entruster only a priority in distribution of the dealer's assets it would be of no value since section 64 of the Bankruptcy Act eliminates state-created priorities. ${ }^{29}$ The entruster as a priority holder would be relegated to the position of an unsecured creditor. If $10(\mathrm{~b})$ creates a statutory lien within the meaning of section $67 \mathrm{c}$ of the Bankruptcy Act his claim would probably be similarly unsecured; section $67 \mathrm{c}(2)$ invalidates statutory liens on personalty not accompanied by "possession of" or by "levy upon" the property subject to the lien before filing of the petition in bankruptcy. ${ }^{30}$ However, a third possibility is that section $10(\mathrm{~b})$

29. 52 STAr. 874 (1938), as amended, 11 U.S.C. $\$ 104$ (1952); Halpert v. Industrial Comm'r, 147 F.2d 375 (2d Cir. 1945) ; Strom v. Peikes, 123 F.2d 1003 (2d Cir. 1941); 3 Collier, Bankruptcy $\llbracket$ 64.01, at 2052 (14th ed., Moore \& Oglebay 1941) (hereinafter cited as Collier).

30. 66 STAT. 428,11 U.S.C. $\$ 107$ (c) (2) (1952) (allowing the trustee in bankruptcy to preserve the lien for the benefit of the estate); 4 CoLLIER $\{67.20$ [5], at 195. In the Matter of Quaker City Uniform Co., 238 F.2d 155 (3d Cir. 1956) (original classification and invalidation of chattel mortgage as a statutory lien modified on rehearing; opinion reserved as to whether chattel mortgage creates statutory lien). 
authorizes a consensual lien which would entitle the entruster to first claim on the bankrupt's assets.

Section $10(\mathrm{~b})$ does not create a statutory lien within the meaning of the Bankruptcy Act. Statutory liens are those not merely regulated, but created by statute for the benefit of particular economic classes. ${ }^{31}$ Thus section $67 \mathrm{~b}$ 's protection of statutory lien holders is limited in application to liens in favor of "employees, contractors, mechanics, landlords or other classes of persons. . .."32 It is unlikely that the term "other classes of persons" is intended to include creditors, such as entrusters, whose security interest, even though regulated by statute, is obtained through a private agreement between the parties.33 Congressional intent further indicates that security devices such as the trust receipt are not statutory liens. Section $67 \mathrm{~b}$ exempts statutory liens from the voiding provisions of section $60 . .^{34}$ This exemption would be illogical for extensively used inventory liens. In addition, section 60 was amended in 1950 to make trust receipts, among other security devices, less vulnerable to invalidation as preferential transfers; this amendment would have been unnecessary if $67 \mathrm{~b}$ already preserved trust receipts liens. ${ }^{35}$ It therefore seems clear that

31. 4 COLLIER If 67.20 [2], at 184 .

32. 30 STat. 564 (1898), as amended, 11 U.S.C. § 107 (b) (1952).

33. See In the Matter of Tele-Tone Radio Corp., 133 F. Supp. 739, 746-48 (D.N.J. 1955) (holding that factor's lien is not statutory); 4 CoLLIER $\llbracket 67.20$ [2], at 184-85 \& n.16b (stating that the UTRA lien is not statutory). But see In re Rand Mining Co., 71 F. Supp. 724, 727 (S.D. Cal. 1947) (dictum that the UTRA lien is statutory) ; Hanna, Prefercnces in Bankruptcy, 15 U. CHI. L. REv. 311, 320 (1948).

34. 30 Stat. 564 (1S98), as amended, 11 U.S.C. $\$ 107$ (b) (1952).

35. In $1950 \$ 60 \mathrm{a}(2)$ of the Bankruptcy Act was amended, 64 STAт. 24,11 U.S.C. $\$ 96$ (a) (1952), to change the standard by which the perfection of liens would be tested. Before this amendment, transfers were deemed to have occurred when they became so perfected that no bona fide purchaser from the dealer could create rights in the property superior to the rights of the transferee. Since the entruster may never obtain rights superior to that of a buyer from the dealer in the ordinary course of trade, UTRA \$ 9-2(a), the entruster's lien could never attain the required perfection. His lien was therefore deemed to have been transferred to the entruster on the eve of bankruptcy, which made the transfer "for or on account of an antecedent debt." The transfer was then vulnerable as a voidable preference. See Bankruptcy Act $\$ 60 a(1), b, 30$ Stat. 562 (1898), as amended, 11 U.S.C. $\$ 96$ (1952). When the transfer was voided, the entruster no longer had a lien to shield from the preferential transfer provisions any money or property received in repayment. In re Harvey Distributing Co., \&8 F. Supp. 466 (E.D. Va. 1950), rev'd sub nom. Coin Mach. Acceptance Corp. v. O'Donnell, 192 F.2d 773 (4th Cir. 1951). This commercially undesirable result was a major reason for amending $\$ 60(a)$ to substitute a judicial lien creditor test for that of a bona fide purchaser. The entruster, in most instances, obtains rights in property superior to that of a judicial lien creditor. Under this test, therefore, his lien may be so perfected by filing that the transfer of the security interest is deemed to have occurred at the time the trust receipt transaction created the debt. Coin Mach. Acceptance Corp. v. O'Donnell, supra at 776 (finding from the history of the 1950 amendment that Congress had originally intended the result prescribed by the amendment); see S. REP. No. 72, 81st Cong., 1st Sess. 1, 3 (1949); Kupfer, The Recent Amendment of Section 60(a) of the Bankruptcy Act, 24 REF. J. 86 (1950); MacLachlan, Preference Redefined, 63 HARv. L. Rev. 1390 (1950). 
section 67b's protection of "statutory liens" does not extend to the entruster's claim under section 10 (b). And, while it is possible that "statutory lien" has a different meaning in $67 \mathrm{c}$, the Bankruptcy Act suggests neither a different definition nor any reason for construing the $67 \mathrm{c}$ term differently. ${ }^{36}$ The invalidating clauses of that section should not, therefore, apply to a section 10 (b) lien.

The most reasonable interpretation is that section $10(\mathrm{~b})$ of the UTRA authorizes a consensual lien on unidentifiable proceeds. Under the terms of this section the entruster is accorded the same rights in proceeds as he had in the goods; he is entitled to proceeds, identifiable or not, "to the extent to which and as against all classes of persons as to whom his security interest was vaild at the time of disposition" of the goods by "the dealer. The entruster's "security interest . . . at the time of disposition" has been held to be a consensual lien on the trust receipted goods $; 37$ the "classes of persons" as against whom this lien has been held valid includes the trustee in bankruptcy. ${ }^{38}$ Hence, section 10 (b) provides the entruster with a lien on unidentifiable proceeds intended to be enforceable in bankruptcy proceedings. ${ }^{38}$

The last clause of section 10 (b), “. . . and to a priority. . .," should in no way weaken or obscure the entruster's rights. ${ }^{40}$ In some instances a debt may be secured by a lien as well as entitled to a priority. ${ }^{41}$ The last clause of section 10(b) was designed to effect just this result. ${ }^{42}$ When the UTRA was promul-

36. See In the Matter of Tele-Tone Radio Corp., 133 F. Supp. 739 (D.N.J. 1955);

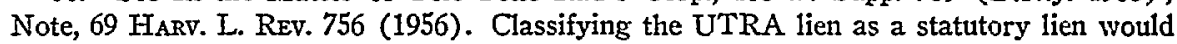
produce further undesirable and arbitrary results. Since $67 \mathrm{c}(2)$ voids statutory liens unaccompanied by possession, the utility of all inventory devices, to which this holding would necessarily be applicable, would be impaired. Accordingly, repossession of inventory would be encouraged, deterring an orderly disposition of the bankrupt's estate. Note, 69 HARV. L. REv. 756, 758 (1956).

37. Taylor v. Quittner, 218 F.2d 549 (9th Cir. 1954); Chichester v. Commercial Credit Co., 37 Cal. App. 2d 439, 99 P.2d 1083 (1940); Donn v. Auto Dealers Inv. Co., 385 I11. 211, 52 N.E.2d 695 (1944).

38. Taylor v. Quittner, supra note 37; Chichester v. Commercial Credit Co., supra note 37.

39. In addition, $\S 18$ states that the provisions of the UTRA should be uniformly and consistently interpreted. Section 10 (b) entitles the entruster to proceeds "whether ... identifiable or not," and all relevant cases have held that the entruster has a lien on identifiable proceeds. Taylor v. Quittner, 218 F.2d 549 (9th Cir. 1954); Universal Credit Co. v. Citizens State Bank, 224 Ind. 1, 64 N.E.2d 28 (1945). Consequently, a uniform and consistent interpretation should require that the entruster's right to unidentifiable proceeds be given the same effect.

40. In the Matter of Harpeth Motors, Inc., 135 F. Supp. 863 (M.D. Tenn. 1955) (overruling a referee's holding that $\$ 10$ provided a mere priority).

41. See, e.g., Bankruptcy Act § 64a, 30 STAT. 563 (1898), as amended, 11 U.S.C. § 104(a) (1952); $\$ 6$ 7b, 30 STAT. 564 (1898), as amended, 11 U.S.C. $\$ 107$ (b) (1952); $\S 67 \mathrm{c}, 66$ STAT. 428,11 U.S.C. $\$ 107$ (c) (1952) (rent, wages and tax claims may have both lien and priority); 3 COLLIER $\uparrow 64.02$, at 2056 (discussing lien and priority of tax claims).

42. The introductory conjunction "and" following a semi-colon makes this clear. See page 928 supra. 
gated in 1933 the Bankruptcy Act did recognize state-created priorities. ${ }^{43}$ Not until five years later did the Chandler Amendment invalidate them, causing the word priority to become a term of art. ${ }^{44}$ In view of this historical background the obsolete usage employed in the last clause of $10(\mathrm{~b})$ should not impair the lien conferred by the first part of this section. Furthermore, the standard distinction between a priority and a valid lien is that the former arises only upon bankruptcy, affording a narrow right to payment at a certain relative point in the distribution of a debtor's property, while the latter entails a right to enforcement independent of bankruptcy. ${ }^{45}$ It is thus apparent that the first part of $10(\mathrm{~b})$, giving the entruster a right to proceeds irrespective of bankruptcy if he makes a timely demand for prompt accounting, provides a lien rather than a priority.

Federal bankruptcy courts should be bound by this interpretation of state law which gives the entruster a lien on the value of proceeds. Section 70 of the Bankruptcy Act and interpretive comments provide that the trustee takes the property in the bankrupt's possession subject to all valid liens. ${ }^{46}$ Nevertheless, the unique dimensions of the entruster's lien on proceeds may raise conceptual difficulties. Since $10(\mathrm{~b})$ entitles the entruster to the "value" of proceeds, ${ }^{47}$ he has a charge against the trustee in bankruptcy on any free assets of the dealer-assets that were not originally subject to the entruster's security interest. The novelty of this 10 (b) lien has troubled some commentators. It has been argued that the entruster can claim the value of proceeds only as a reclamation petitioner, on the theory that he is the beneficiary of a trust. $^{48}$ If this were true, standard trust law would require that the entruster identify and trace proceeds of sale. ${ }^{49}$ The proceeds are often cash, and it may be impossible to trace them into a particular bank account or newly acquired property. However, the UTRA clearly dispels the trust analogy. Section 1 cleclares that " $[t]$ he use of the word 'Trustee' . . . shall not be interpreted or construed to imply the existence of a trust ..."; section 10(b) eliminates any identification requirement. ${ }^{50}$ In bankruptcy proceedings state law is deter-

43. 30 STAT. 563 (1898) (later amended by 52 STAT. 874 (1938), 11 U.S.C. \& 104 (1952)); see note 29 supra and accompanying text.

44. Ibid.

45. 3 COLLIER I 64.02, at 2055-56; In the Matter of Harpeth Motors, Inc., 135 F. Supp. 863 (M.D. Tenn. 1955) (quoting from CoLLIER) ; cf. Note, 51 Yale L.J. 863, 868 (1942); Prudence Realization Corp. v. Geist, 316 U.S. 89 (1942).

46. 30 SтAт. 565 (1898), 11 U.S.C. $\$ 110$ (1952); 4 Collies $\{70.04$, at $947 \&$ n.20 (collecting cases).

47. See page 928 supra.

48. Gilmore, Chattel Security: II, 57 Y YLE L.J. 761, 768 (1948) suggests that the trust analogy may be necessary to support the entruster's claim to proceeds. See also In the Matter of Harpeth Motors, Inc., 135 F. Supp. 863, 869 (M.D. Tenn. 1955) (disagreeing with, although not overruling, the referee's contention that the entruster's claim could not be enforced unless he traced proceeds of sale).

49. 4 Collier If 70.25, at 1134; 4 ScotT, Trusts $\$ 521$ (2d ed. 1956).

50. In the Matter of Harpeth Motors, Inc., 135 F. Supp. 863, 869 (M.D. Tenn. 1955); Heind, Trust Receipt Financing Under the Uniform Trust Receipts Act, 26 CHI.-KENT 
minative as to the existence of a trust and tracing requirements, unless it substantially departs from the general norm of trust law. ${ }^{51}$ Certainly the provisions of a uniform law adopted in thirty-one states cannot be considered aberrational and should be followed by federal bankruptcy courts. ${ }^{62}$ Moreover, normally state law, not the Bankruptcy Act, also determines what liens are valid, for the act nowhere states any affirmative requirements of a valid lien. ${ }^{53}$ It is true that liens defined as valid by state law often are, or lead to, transfers of property interests which may be voidable under the Bankruptcy Act's express provisions against preferential and fraudulent transfers. ${ }^{54}$ But the entruster can meet these requirements by filing under the UTRA. ${ }^{55}$ When he does, the Bankruptcy Act imposes no further obstacle to a section 10(b) lien on free assets of the bankrupt dealer. ${ }^{56}$

The validity of the UTRA lien on the value of proceeds, however, should be conditioned on the entruster's prompt prosecution of his claim. ${ }^{57}$ Section 10 makes the entruster's demand for a prompt accounting within ten days of sale necessary for the preservation of his security interest. ${ }^{58} \mathrm{~A}$ demand for

L. REv. 197, 258 (1948) ; Bogert, The Effect of the Trust Receipts Act, 3 U. CEI. L. REv. 26, 37 (1935).

51. Even though Congress might preempt state law in this area, it has not done so. 4 COLIIER $\int$ 70.25, at 1148-49. Bankruptcy courts, consequently, must refer to state law on these questions. Ibid. They may, however, overrule any state law which, if applied, would effect a state insolvency rule rather than the bankruptcy rule of distribution. Ibid. See In re Tate-Jones \& Co., 85 F. Supp. 971 (W.D. Pa. 1949) (citing Collier) ; cf. Prudence Realization Corp. v. Geist, 316 U.S. 89 (1942).

52. See note 51 supra. By enacting the 1950 amendments to $\S 60$, Congress has, in fact, evidenced an intent not to use its bankruptcy power to preempt state rules on trust receipts. See note 35 supra.

53. 4 COLLIER If 70.70, at $1343-47$ (collecting cases).

54. See Bankruptcy Act $\$ 60 a, b, 30$ Srar. 562 (1898), 11 U.S.C. $\$ 96$ (a) (b) (1952); \$ 67d, 30 Stat. 564 (1898), 11 U.S.C. $\$ 107$ (d) (1952); \& 70c, 30 Star. 566 (1898), 11 U.S.C. $\$ 110$ (c) (1952); \& 70e, 30 Stat. 566 (1898), 11 U.S.C. $\$ 110(e)$ (1952).

55. If the entruster's security interest is valid under the UTRA and he has properly filed, it may not be avoided under : $\$ 67 d$ (provided the entruster has given fair consider-

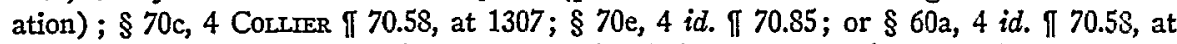
1308 \& n.27a, and see note 35 supra. See also 3 ColiIER If 60.45, at 958-59 (discussing whether filing must take place within twenty-one days after transaction under $\S 60 \mathrm{a}(7)$, or within thirty days under UTRA $\$ \S 7,8,9$; Note, 66 YALE L.J. 567, 575 \& n.40 (1957) (same).

56. 4 ColiIER if 70.70 , at $1344-46$ (collecting cases).

57. Dealers often take used cars from consumers as part of the retail price of entrusted automobiles. When the dealer fails to repay his entire debt on the new car, the entruster should be permitted to maintain a security interest in this type of proceeds without immediately prosecuting his claim only if he secures a chattel mortgage, a new trust receipt (in states where this is possible), or some other security device on the used automobile.

58. Although the period of time during which the entruster's lien on proceeds survives before he demands an accounting ostensibly varies under $\S 10(\mathrm{a}), \S 10(\mathrm{~b})$ and $\S 10(\mathrm{c})$, it is unlikely that $\S 10$ (a) or $\S 10$ (c) will be interpreted to permit the entruster to remain safely inactive for appreciably longer than the ten day limit of $\S 10(\mathrm{~b})$. The effect of 
prompt accounting has been held to mean that the entruster must demand immediate delivery of the proceeds from the dealer. ${ }^{59}$ But neither the UTRA nor case law has considered whether the entruster's lien should be contingent upon any further action if the dealer fails to comply with this demand. The most reasonable construction of the demand for accounting requirement would necessitate that the entruster diligently bring suit for the proceeds upon the dealer's default or lose his security interest in them. Since a creditor knows that cash proceeds are easily dissipated in the course of business, the entruster who permits a dealer to continue business without promptly enforcing his lien, depends, just as any unsecured creditor, on the dealer's honesty and continued solvency rather than on his collateral. Thus he should be placed in no better position than unsecured creditors in bankruptcy and nonbankruptcy proceedings. In either type of proceeding failure to sue immediately after a prompt demand for an accounting should dissolve the entruster's lien, except if a petition in bankruptcy was filed by or against the dealer within ten days after sale. ${ }^{60}$ Outside of bankruptcy, if an unsecured creditor effects a prior attachment on property of the dealer, the entruster should be compelled to take effective action adverse to that creditor's interest in order to maintain a superior lien on this property. ${ }^{61}$

Once the entruster's lien on the value of cash proceeds is conditioned on his diligent enforcement it is not at all inequitable to accord him the favored status of a secured creditor. Because the entruster is usually the dealer's most signifi-

this time limit is to force the entruster to police the dealer's activities diligently. Section 10 (c) may seem to extend this time limit when the proceeds of sale are identifiable. The entruster is held to a waiver of his security interest if he fails to demand an accounting within ten days after his "knowledge" that such proceeds existed. But, since the entruster is forced to maintain constant surveillance over the dealer in order to preserve his security interest in unidentifiable proceeds, he will probably be held to at least constructive knowledge of the existence of identifiable proceeds shortly after they are received by the dealer.

Section 10 (a), which gives the entruster a security interest in debts owing to the dealer by reason of the sale of collateral, apparently does not condition this right upon any affirmative action by the entruster. This section becomes important in the rather unusual occurrence of a dealer retaining a conditional sales contract. The entruster may then attempt to claim this form of identifiable proceeds under $\S 10$ (a) and subsequently claim the installment payments without showing that he made a timely demand for an accounting after the dealer initially received this consumer paper. Since the Commissioners' Prefatory Note, 9A U.L.A. 282, explains that the act "deprives the entruster of the altogether improper possibility of acting like a mere creditor while things go well, but insisting on his rights ... if things go badly," it is quite unlikely that $\S 10$ (a) was intended to permit the entruster to act "like a mere creditor" indefinitely. The most reasonable conclusion, consequently, is that the general ten day period common to $\S \S 10$ (b) and (c) is applicable to the entruster's rights under $\S 10$ (a) as well.

59. Peoples Finance and Thrift Co. v. Bowman, 58 Cal. App. 2d 729, 734-35, 137 P.2d 729, 731-32 (1943).

60. See UTRA $\S 10(\mathrm{~b})$, sutpra page 928.

61. Such action may include intervening in the other creditor's suit (in states where possible, Clark, Code Pleading 420-23 (2d ed. 1947)), enjoining the other creditor's action, or bringing a bill to marshal the liens and sell the property. 
cant creditor, in terms of importance to the business and of dollar amount, the substantial risks of dealer insolvency lie with him rather than with the unsecured creditors. ${ }^{62}$ For this reason the entruster takes a number of measures to protect his interest. He gives notice of his claim by recording a statement of inventory financing ${ }^{63}$ and conducts an extensive examination into the business background of the dealer. ${ }^{64} \mathrm{He}$ arranges for regular physical inspections of the dealer's trust receipted inventory, which are intensified if signs of trouble are disclosed, ${ }^{65}$ and makes a prompt demand for repayment each time collateral is sold. ${ }^{66}$ The unsecured creditors, on the other hand, do not customarily take any of these precautions. Moreover, the entruster has entered into the financing arrangement relying ultimately for payment upon his security interest in the value of proceeds. He expects to be paid an amount equal to the wholesale cost of the goods from the proceeds of sale, whereas the unsecured creditors can expect satisfaction only from the mark-up retained by the dealer. Thus if unsecured creditors have depended upon any specific part of the dealer's assets it has been on net receipts-income above cost of goods sold-rather than on gross receipts which, to the greatest extent, have been made possible by the entruster. Therefore, since the entruster does lose his lien on the goods themselves, ${ }^{67}$ and should lose his claim to a conditional sales contract taken in good faith by another finance company, ${ }^{68}$ he should be accorded a security interest in the value of proceeds upon which he has relied and against which he has diligently proceeded.

62. See Hanna, Preferences in Bankruptcy, 15 U. CHr. L. REv. 311, 314-15 (1948).

63. See note 4 supra. But see Note, 66 Y ALE L.J. 567, 574 \& n.31 (1957) (collecting authorities which question the value of notice filing).

64. Serdaran, Finance Companies and Factors 104-06 (1949).

65. See $i d$. at $97-98$; Heindl, supra note 50 , at 259 .

66. See note 58 supra.

67. UTRA § 9-2(a).

68. See notes 15-28 supra and accompanying text. 